\title{
Perceived Impact of Supplementary Private Tutoring on Students: the case of Upper Primary School Students
}

\author{
Wudu Melese Tarekegne ${ }^{1, *} \&$ Mekuria Abebe Kebede ${ }^{1}$ \\ ${ }^{1}$ Department of Teacher Education and Curriculum Studies, Jimma University, Jimma, \\ Ethiopia \\ *Corresponding author: Department of Teacher Education and Curriculum Studies, Jimma \\ University, Jimma, Ethiopia. Tel: 251-917-800-912 E-mail: wudumelese@gmail.com
}

Received: September 22, 2016 Accepted: August 2, 2017 Published: November 15, 2017

doi:10.5296/ije.v9i4.10062 URL: https://doi.org/10.5296/ije.v9i4.10062

\begin{abstract}
This study was aimed at assessing the perceived impact of supplementary private tutoring on upper primary school students of Ethiopia. To achieve this objective a cross-sectional survey research design was employed. Accordingly, four regions and one city administration were selected as sample regions by using simple random sampling method. Again from each region the capital town of each sample regions was selected as sample towns through purposive sampling technique. Then from each sample town three government and three private schools were selected by simple random sampling technique. Consequently, from each selected sample schools 50 percent of the students and all the teachers and the principal of the school were taken by purposive sampling techniques. Data were collected from sample students, teachers, and principals through the use of questionnaires, interview, and focus group discussion. The result reveals that the amount of money they pay is relatively big in Ethiopian context so that it is a burden for the family. On the other hand, supplementary private tutoring helps students understanding of the subject matter, provide different support and increase the self-confidence of the students, and improve students' achievement result. Moreover, supplementary private tutoring did not consume students' spare time, not result in social stigma of students, it is not boring, it did not requires much and extra effort, the work they do with their tutors is the same activity as they do in school and it did not confuse them.
\end{abstract}

Key words: Perceived Impact, Supplementary Tutoring, Upper Primary School, Ethiopia 


\section{Background of the Study}

\subsection{Introduction}

It is a widely accepted fact that education is regarded as a necessary determinant of a person's productivity and economic growth of countries. Education has been widely considered as one of the important determinants of an individual's productivity and economic growth of countries. Aggarwal (1998) argued that one of the major activities that enhance human capital is education which is highly linked to that education linked to individuals' earnings and growth of economy. To search evidence of the connection between education to individual's productivity and economic growth, researchers have focused largely on formal education (both public and private sectors). There are ample of studies that investigate how increases in both quantity and quality of schooling are related to students' academic achievement and labor market outcomes as well as economic development. Nevertheless, there is a shortage of studies that investigate the effect of private tutoring, a form of supplementary education where students can acquire more skills and knowledge to increase their human capital. This is an important area in education as private tutoring becomes a growing phenomenon in many countries (Dang \& Rogers, 2008). Supplementary private tutoring is expanding in many countries of the world as a result it is considered as the third emerging education sector in addition to public and private school sectors.

Policy makers of developing countries understand that the main determinant of one's productivity and economic wide growth is education. However, their sector analysis and policy attentions focused on public education; whereas less attention has been paid to private school sectors and supplementary private tutoring industry (Bajaj \& Belinda, 2009).

Developing country policy makers give due attention to education particularly school based education in the last two decades, since they realize the importance of education in the development of human capital and economic growth. Their committeemen is reflected in the second Millennium Development Goal which states that all children, whether boys and girls, should be able to complete a full course of primary schooling (Bray, 2003).

Accordingly, a critical and rigorous analysis of policies surrounding provision of school-based education has received much-deserved attention (Glewwe et al, 2013; Hanushek, 2003). However, in the process of analysis the contribution of supplementary educational inputs given by the families, such as shadow education has remained neglected. Private tutoring can be conceptualized as fee-based tutoring that provides supplementary instruction to children in academic subjects that they study in the mainstream education system (Dang \& Rogers, 2008). It is widespread across many developing as well as developed countries.

Nowadays, in many countries of the world, supplementary private tutoring has grown as parallel education sector that offers support to students who attend in public school (Baker et al., 2001; Bray, 1999). For example, it has existed for decades in Japan, where more than half of today's middle school students receive some type of academic tutoring outside school (Monbukagakusho, 2008). Families pay for tutoring, expecting these extra lessons to increase their children's academic achievement. In the United States, supplementary tutoring was 
relatively unknown in the past. However, it has grown over the past decades, especially under the No Child Left Behind (NCLB) legislation that uses such out-of-school lessons to boost students' academic achievement. Indeed, tutoring practices have experienced a rapid expansion in the U.S. due to the competitive pressure of high-stakes achievement tests (Russell, 2002; Sullivan, 2010).

Supplementary tutoring is perceived as an out-of-school academic practice to improve the learning of students. In fact, the assumption is when students devote more of their time on subject matter learning, they will eventually learn more and better and be successful in examinations. Generally, research results related to the effect of supplementary private tutoring are inconclusive (Bray, 2011). Nevertheless, a few research findings showed that private tutoring have an impact on students' academic performance. Some of the findings revealed that students who received supplementary private tutoring had a better reading performance, less frequent grade repetition and a better academic performance in general, while other studies indicated no relationship between their performance and whether or not they had been privately tutored.

Similarly many studies indicated a positive impact of supplementary private tutoring on students examination score (Lavy \& Schlosser, 2005; Dang 2007; Banerjee et al., 2007). While others showed either no impact or even a negative impact of private tutoring on academic performance (Suryadarma et al., 2006; Cheo \& Quah, 2005). Still other studies depicted the impact of private tutoring was found to be related to the fields of competence. For instance, Tran Thu Ha and Trudy Harpham (2005) reported that it has a positive effect on reading, but negligible effect on writing and numeracy. Likewise, Alvaro Choi et al. (2011) indicated that the impact is positive for mathematics and positive but decreasing for reading, but insignificant for the natural sciences.

Generally, supplementary private tutoring is regarded as a hot issue in many countries which has been extensively discussed by Bray et al. (2013). There are two research findings one by Mendes et al., (2013) in Portugal and the other by Simona (2007) in Romania for which a positive impact of private tutoring on academic achievement were reported. Yet, these studies do not attempt to answer the question of the impact of private tutoring on academic performance measured in terms of the standardized national test scores.

\subsection{Statement of the Problem}

Private supplementary tutoring is a phenomenon which is common all over the world including Ethiopia. Even though there is no documented empirical evidence that is directly focused on private tutoring practice in Ethiopia a study by the World Bank (2012: 79) on corruption in Ethiopian Education sector indirectly made clear that “...poorly paid teachers supplement their income by 'private tutoring' [which] is wide spread with $40 \%$ of school officials reporting it as a practice". This study indicates that private tutoring exists in Ethiopian schools yet the empirical status of it is not known clearly.

Besides, during recent decades, private tutoring has grown to become a vast enterprise. It employs many thousands of people, consumes massive amounts of money, and demands huge 
amounts of time from both tutors and students (Ireson, 2004; Kirss, 2011; Dawson, 2010). Nevertheless, most policy makers do not have appropriate and adequate evidence on private tutoring and its implication for mainstream education system and for social change are under-restricted and poorly understood.

In addition to the above point experience shows that in parallel to the formal education system in wide range of settings there is supplementary private tutoring. However, private tutoring systems have received much less attention, even though they also have major social and economic implications. Moreover, to the best knowledge of the researchers there is little or no research conducted that shows the effect of supplementary private tutoring on students. Therefore, this study is a first attempt in this country to document systematically the impact (academic, social and economic) of private tutoring on the education system of the country. To see this the following research questions were formulated:

- What is the perceived academic impact of private tutoring on students?

- What is the perceived social impact of private tutoring on students?

- What is the perceived economic impact of private tutoring on students?

\subsection{Objectives of the Study}

The general objective of this study is to assess the perceived impact of supplementary private tutoring on students in Ethiopia. More specifically, the objectives of this study is:

$>$ Investigate the perceived academic impact of private tutoring on students

$>$ Examine the perceived social impact of private tutoring on students

Assess the perceived economic impact of private tutoring on students

Realizing the above objectives would have a paramount importance for the policy makers in education to be aware and take necessary measures for the enhancement of this significant system of education but not addressed in the policy. In addition, it also would help for curriculum designers and educational planners to consider the implication of private tutoring in developing their plan.

\section{Method}

\subsection{Design of the Study}

To identify the perceived impact of private supplementary tutoring in the upper primary schools of Ethiopia a cross-sectional survey research design was employed. This research design is used because it is used to examine the perceived impact of private supplementary tutoring supplementary in the elementary schools of Ethiopia. Moreover, this design is appropriate since the study is a national survey by taking representative samples. 


\subsection{Population, Sample and Sampling Techniques}

The population of this study is all the upper primary (grades 5-8) schools of Ethiopia. However, due to time and resource this research was conducted in some selected school found in the major town of the country. Accordingly, from the total regional states and city administrations of the country four regions (two from the relatively developed and two from the emerging regions) and one city administration were selected as sample regions by using simple random sampling technique. Again from each region the capital town of each sample regions was selected as sample towns through purposive sampling method. Then from each sample town three government and three private schools were selected by simple random sampling technique. Consequently, from each selected sample schools 50 percent of the students and all the teachers of the sample schools and the principal of the school were taken as sample of the study by purposive sampling techniques. Moreover, one student from each section in the sample school was selected randomly for focus group discussion. Generally, a total of 13 government schools and 13 private schools were taken as a sample schools due to shortage of resource (finance) and shortage of time. The following table shows the sample region/towns and number of sample students, teachers and principals.

Table 1. Study Sample Region and Study Participants

\begin{tabular}{lllll}
\hline No. & Regions/ City administration & $\begin{array}{l}\text { Number of sample } \\
\text { students }\end{array}$ & $\begin{array}{l}\text { Number of } \\
\text { sample } \\
\text { teachers }\end{array}$ & $\begin{array}{l}\text { Number of } \\
\text { sample } \\
\text { principals }\end{array}$ \\
\hline 1 & Amhara Region & 198 & 71 & 6 \\
2 & Oromiya Region & 192 & 97 & 6 \\
3 & Benishangul-Gumuz Region & 136 & 56 & 4 \\
4 & Gambela Peoples' Region & 82 & 58 & 4 \\
5 & Addis Ababa City Administration & 258 & 88 & 6 \\
\hline & Total & 866 & 370 & 26 \\
\hline
\end{tabular}

\subsection{Instruments of Data Collection}

Data were collected from the sample participants by using the following instruments:

\subsubsection{Questionnaire}

In order to examine the perceived impact of supplementary private tutoring in Ethiopian upper primary schools, structured survey questionnaires were developed and administered to selected sample upper primary school students, and teachers. Different questionnaires were prepared for students and teachers. Generally, the questionnaires were designed in a way that would help the researchers extract detailed data about the current practice of private tutoring in Ethiopian upper primary schools. All the questionnaires were prepared in Amharic (local language) to easy communication and get relevant data from the sample respondents. 


\subsubsection{Interview}

Semi-structured interview guide question was prepared based on the review of literature for school principals on the practice of private tutoring. Interview was conducted with the school principal on the perceived impact of supplementary private tutoring in upper primary students.

\subsubsection{Focus Group Discussion}

Focus group discussion guiding questions were prepared in advance and then students from different sections in the same school (when there are more than one sections) was selected for focus group discussion. One focus group discussion was conducted in one school.

\subsection{Pilot Testing of the Instrument}

To maintain the validity and reliability of the instrument a pilot test was conducted by selecting one private and one government schools in Jimma town. Before distributing to the sample participants the instrument was given to two experts in education in Jimma University to evaluate the validity of the items and comments were incorporated. Subsequently the instruments were prepared and distributed to participants of the study and then the results were processed through SPSS. The reliability coefficient of the instrument was calculated to be (.79) which is regarded as strong correlation coefficient by Jackson (2009). After that the final instruments were administered to all sample participants and enough time was given for them to fill and return it.

\subsection{Methods of Data Analysis}

The data collected were analyzed based on the nature of the data that is, the quantitative data collected were analyzed by using descriptive statistics such as by the use of frequency and percentage. On the other hand, qualitative data collected through the use of interview and focus group discussion were transcribed, coded based on themes and described qualitatively through the use of word narrations.

\subsection{Ethical Issues}

To maintain the ethical issue the participants of the study were requested their consent before they are asked to fill the questionnaires and participate in the interview. In addition, the researchers made clear that the information that the participants provide will not be given to a third party. As a result, the data they provide were used only for the study purpose. Moreover, the researcher ensured confidentiality by making the participants anonymous.

\section{Result}

Supplementary tutoring is considered as a shadow of the formal education; it still affects and affects not only individuals, but also whole societies. This result section of the paper tries to describe impact of private supplementary tutoring on mainstream schooling. In this section the result is presented in line with the research question that is first its economic effect will be 
presented followed by the educational and social impacts.

\subsection{Economic Impact}

One of the features of supplementary private tutoring is cost; since supplementary private tutoring involves by tutors for financial gain. To see the economic impact of supplementary private tutoring on Ethiopian household income and to help in estimating the of the amount of expenditure each student pay for supplementary private tutoring and the extent to which these expenditures were a burden on household budgets, students and teachers were asked their perception and the result is presented in the table below.

Table 2. The Amount of Expenditure for Supplementary Private Tutoring and Its Effect on Family

\begin{tabular}{lllll}
\hline Item & student & \multicolumn{3}{c}{ teacher } \\
\cline { 2 - 6 } & $\#$ & $\%$ & $\#$ & $\%$ \\
\hline $\begin{array}{l}\text { The amount of money (your) parents pay for the tutorial per } \\
\text { month }\end{array}$ & 114 & 13.7 & 20 & 7.3 \\
A. Less than 100 Birr & 184 & 22.7 & 100 & 36.5 \\
B. 100-200 Birr & 132 & 16.3 & 52 & 19 \\
C. 200-300 Birr & 382 & 47.1 & 98 & 35.8 \\
D. Greater than 300 Birr & & & & \\
\hline Total & 812 & 100 & 270 & 100 \\
\hline How big is the financial commitment for (your) family? & & & & \\
A. Very big & 66 & 7.9 & 36 & 12.5 \\
B. Relatively big, but not prohibitively expensive & 156 & 18.7 & 80 & 27.8 \\
C. It is simple & 288 & 34.4 & 42 & 14.6 \\
D. I do not know & 336 & 39.0 & 98 & 34.0 \\
\hline Total & 846 & 100 & 256 & 100 \\
\hline
\end{tabular}

As it is indicated in the above table 47.1 percent of students affirmed that the amount of money their parents pay for supplementary private tutoring is greater than 300 Ethiopian birr ( $>\$ 15)$ per month whereas, a small proportion of students 13.7 percent replied that the amount is less than 100 Ethiopian Birr. Similarly, teachers were asked the amount of money they receive while they give tutorial for a single student and the result shows that 36.5 percent and 35.8 percent the teachers verify that they receive 100 up to 200 Ethiopian Birr and greater than 300 Ethiopian Birr respectively.

Table 2 also indicates the responses to the question whether the costs of tutoring were a burden to the students' families or not. As it is indicated 39 percent and 34.4 percent affirmed that they do not know the burden of the expenditure for the family and it is simple respectively. Whereas a relatively a small proportion of respondents 7.9 percent revealed that the burden is very big. Likewise teachers were also requested to estimate the extent of burden on students parent the amount of money they pay for supplementary private tutoring. The 
result shows that 34 percent and 27 percent of the teachers indicated that they do not have information about the burden and it is relatively big, but not prohibitively expensive respectively.

On the other hand, school principals were also interviewed on this issue and they confirmed that it is a burden for the parent. For instance, one of the principals described that "I heard from the parents that the amount of money they pay for supplementary tutoring is becoming a burden for them and they will not continue paying for supplementary private tutoring".

\subsection{Academic Impact}

Supplementary private tutoring /shadow education/ has many types of impact. One of the most obvious is on academic achievement. In addition, shadow education may shape broader skills and the values of both recipients and wider societies. It may have an impact on the efficiency of education systems; and it has considerable implications for inequalities and perhaps also for social cohesion.

Shadow education is believed by many people that it contributes for students' academic achievement of students that is why many families invest on it. However, this assumption depends on both the quality of tutoring and the interest and motivation of students.

To examine the contribution of supplementary private tutoring program on students' academic performance improvement, participant students were asked their perception on the effect of supplementary private tutoring on the improvement of their score and their response is presented below.

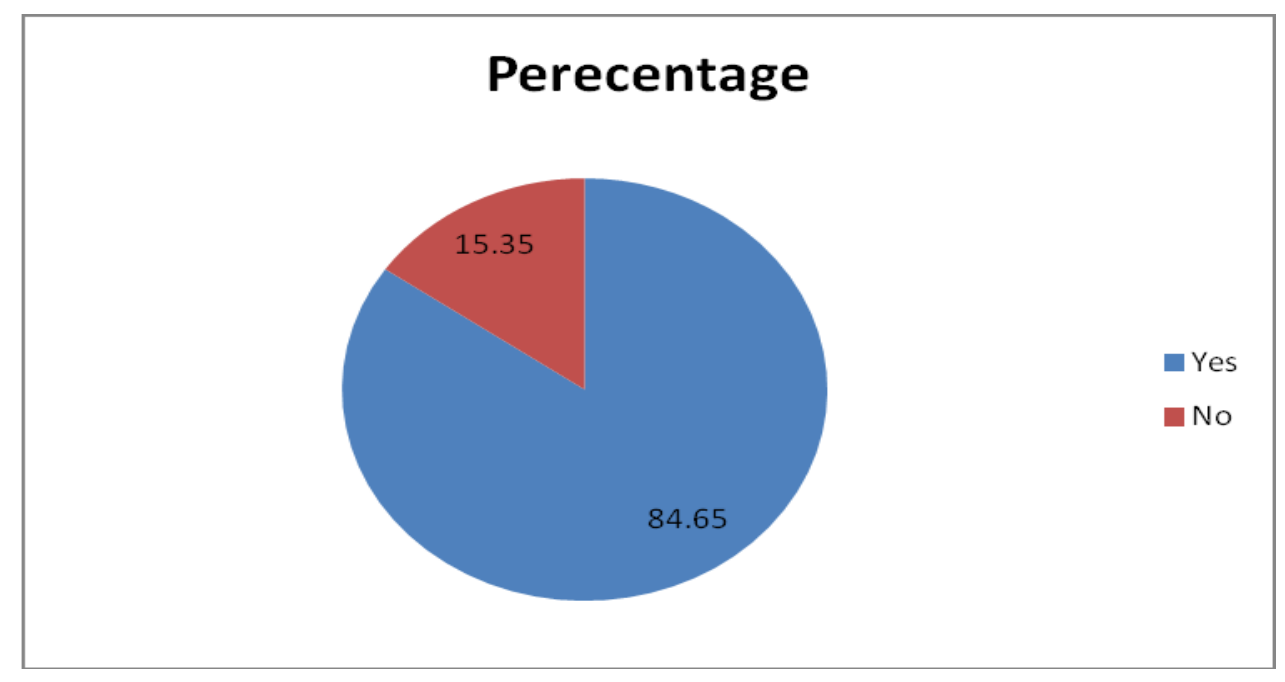

Figure 1. The Contribution of Supplementary Private Tutoring for Students' Performance in School

As it is presented in the Figure 1 above a great majority of participant students $(84.65 \%)$ believe that their participation in extra supplementary private tutoring helped them to attain good marks in school. Whereas, the rest of them (15.35\%) replied that it did not help them to get better result in their schooling. 
Moreover, to assess the perceived academic impact of supplementary private tutoring, both students and teachers were requested to tick the possible advantages of supplementary private tutoring and their response is presented in the following table.

Table 3. Perceived Advantages of Supplementary Private Tutoring on Academic

\begin{tabular}{|c|c|c|c|c|c|c|c|c|c|c|c|c|c|}
\hline \multirow[t]{3}{*}{ No. } & \multirow[t]{3}{*}{ Item } & \multicolumn{6}{|c|}{ Student } & \multicolumn{6}{|c|}{ Teacher } \\
\hline & & \multicolumn{2}{|l|}{ Yes } & \multicolumn{2}{|l|}{ No } & \multicolumn{2}{|c|}{ Total } & \multicolumn{2}{|l|}{ Yes } & \multicolumn{2}{|l|}{ No } & \multicolumn{2}{|c|}{ Total } \\
\hline & & $\#$ & $\%$ & $\#$ & $\%$ & $\#$ & $\%$ & $\#$ & $\%$ & $\#$ & $\%$ & $\#$ & $\%$ \\
\hline 1 & $\begin{array}{l}\text { To improve understanding } \\
\text { of the subject }\end{array}$ & 795 & 93 & 60 & 6.8 & 855 & 100 & 348 & 98.1 & 7 & 1.9 & 355 & 100 \\
\hline 2 & To increase self confidence & 719 & 84 & 137 & 16 & 856 & 100 & 330 & 92.9 & 25 & 7.1 & 355 & 100 \\
\hline 3 & $\begin{array}{l}\text { To help achieve the highest } \\
\text { examination grades }\end{array}$ & 796 & 93 & 60 & 7 & 856 & 100 & 336 & 94.8 & 18 & 5.2 & 354 & 100 \\
\hline 4 & I get one-to-one help & 728 & 85.1 & 128 & 14.9 & 856 & 100 & 320 & 90.3 & 34 & 9.7 & 354 & 100 \\
\hline 5 & $\begin{array}{l}\text { Having a tutor helps me do } \\
\text { better in school }\end{array}$ & 769 & 89.9 & 86 & 10.1 & 855 & 100 & 329 & 92.9 & 25 & 7.1 & 354 & 100 \\
\hline 6 & $\begin{array}{l}\text { Things are explained to me } \\
\text { in more detail }\end{array}$ & 749 & 87.5 & 107 & 92.5 & 856 & 100 & 326 & 92.2 & 28 & 7.8 & 354 & 100 \\
\hline 7 & $\begin{array}{l}\text { Having a tutor gives me } \\
\text { someone to talk to }\end{array}$ & 720 & 84.2 & 135 & 15.8 & 855 & 100 & 308 & 87 & 46 & 13 & 354 & 100 \\
\hline 8 & $\begin{array}{l}\text { They explain things that I } \\
\text { do not understand in school }\end{array}$ & 756 & 88.5 & 98 & 11.5 & 854 & 100 & 346 & 97.4 & 9 & 2.6 & 355 & 100 \\
\hline 9 & $\begin{array}{l}\text { You can ask them any } \\
\text { questions }\end{array}$ & 769 & 89.7 & 86 & 10.1 & 855 & 100 & 322 & 90.9 & 32 & 9.1 & 354 & 100 \\
\hline 10 & You get more work done & 744 & 87 & 111 & 13 & 855 & 100 & 317 & 89.6 & 37 & 10.4 & 354 & 100 \\
\hline 11 & $\begin{array}{l}\text { You can learn at a quicker } \\
\text { pace than at school }\end{array}$ & 765 & 79.1 & 180 & 20.7 & 855 & 100 & 300 & 85 & 53 & 15 & 353 & 100 \\
\hline
\end{tabular}

As it is indicated in the above table both the students and teachers response are summarized on the different issues related to the perceived effect of supplementary tutoring from the perspectives of the students and the teachers.

Question number 1, 6, 8, and 11 in Table 3 asks about the impact of supplementary private tutoring on the students understanding of the subject matter that the students learn in the mainstream program. A large percentage of students believe that supplementary private tutoring helped them to understand the subject and do more. For instance, 93 percent of the students believed that it helped them to improve understanding of the subject, 87.5 percent confirmed that it helped to make things are explained to them in more detail, 88.5 percent confirmed that it helped them to explain things that they do not understand in school, and 79.1 percent attested that it helped them to learn at a quicker pace than at school. Similarly, almost the same percentage of teacher respondents confirmed the same affirmative responses 


\section{Al Macrothink}

International Journal of Education

ISSN 1948-5476

2017, Vol. 9, No. 4

to the questions related to supplementary private tutoring role on students understanding of the subject matter.

Likewise one of the principal described by saying "To tell you frankly tutoring can be tailored to the needs of the students as it allows the tutor to develop a good knowledge of the student's strength and weakness." From this description it is possible to understand that private supplementary tutoring is valuable for the students since it helps the students to learn based on his/her pace.

Question number 4, 7, and 9, in Table 3 asks about the contribution of supplementary private tutoring on the different support it provides for the students. A significant percentage of students confirmed supplementary private tutoring enabled them to acquire valuable support from the tutors. For instance, 85.1 percent of the students reported that they get one-to-one help, 84.2 percent of the respondents replied that having a tutor give them someone to talk to, and 89.7 percent of the students attested that they can ask them any questions. The same percentage of teacher respondents confirmed the same affirmative responses to the questions related to the contribution of supplementary private tutoring in different support it provides for the students.

Question number 2, in Table 3 asks about the role of supplementary private tutoring on increasing the confidence of students. A large percentage of students $(84 \%)$ believe that it helped them to develop self confidence. Similarly, when teachers are asked the same question a great majority $(92.9 \%)$ of respondents believe that supplementary private tutoring helped students to develop a self confidence.

Question number 3 and 5, in Table 3 asks about the perceived impact of supplementary private tutoring on the improvement of students achievement result. A greater percentage of students for instance 93 percent and 89.9 percent of students believed that supplementary private tutoring helps them to achieve the highest examination grades and helps them do better in school respectively. Likewise, teachers also confirmed the same response $(94.8$ percent and 92.9 percent) for the former and the later respectively.

\subsection{Social Impact}

To assess the perceived negative impact of supplementary private tutoring, both students and teachers were requested to tick the possible disadvantages of supplementary private tutoring and their response is presented in the following table. 
Table 4. The Negative Impact of Supplementary Private Tutoring

\begin{tabular}{|c|c|c|c|c|c|c|c|c|c|c|c|c|c|}
\hline \multirow[t]{3}{*}{ No. } & \multirow[t]{3}{*}{ Item } & \multicolumn{6}{|c|}{ Student } & \multicolumn{6}{|c|}{ Teacher } \\
\hline & & \multicolumn{2}{|l|}{ Yes } & \multicolumn{2}{|l|}{ No } & \multicolumn{2}{|c|}{ Total } & \multicolumn{2}{|c|}{ Yes } & \multicolumn{2}{|l|}{ No } & \multicolumn{2}{|c|}{ Total } \\
\hline & & $\#$ & $\%$ & \# & $\%$ & $\#$ & $\%$ & $\#$ & $\%$ & \# & $\%$ & $\#$ & $\%$ \\
\hline 1 & $\begin{array}{l}\text { Tutoring takes up my } \\
\text { spare time }\end{array}$ & 168 & 19.7 & 684 & 80.3 & 852 & 100 & 78 & 22.2 & 275 & 77.8 & 353 & 100 \\
\hline 2 & $\begin{array}{l}\text { I get teased because I } \\
\text { have a tutor }\end{array}$ & 75 & 8.8 & 777 & 91.2 & 852 & 100 & 14 & 3.9 & 340 & 96.1 & 354 & 100 \\
\hline 3 & It's boring & 119 & 14 & 732 & 86.0 & 851 & 100 & 76 & 21.4 & 278 & 78.6 & 354 & 100 \\
\hline 4 & $\begin{array}{l}\text { Most of the work my } \\
\text { tutor gives me is too } \\
\text { easy }\end{array}$ & 245 & 28.3 & 607 & 71.2 & 852 & 100 & 92 & 26.1 & 262 & 73.9 & 353 & 100 \\
\hline 5 & $\begin{array}{l}\text { You have to do more } \\
\text { work }\end{array}$ & 104 & 12.2 & 748 & 87.8 & 852 & 100 & 81 & 22.9 & 273 & 77.1 & 353 & 100 \\
\hline 6 & $\begin{array}{l}\text { Sometimes the work I } \\
\text { do with my tutor is } \\
\text { different to the work I } \\
\text { do in school and } \\
\text { confuses me }\end{array}$ & 118 & 13.9 & 734 & 86.1 & 852 & 100 & 76 & 21.4 & 278 & 78.6 & 354 & 100 \\
\hline 7 & $\begin{array}{l}\text { I feel embarrassed to } \\
\text { have a tutor }\end{array}$ & 75 & 8.8 & 777 & 91.2 & 852 & 100 & 18 & 5.2 & 336 & 94.8 & 354 & 100 \\
\hline
\end{tabular}

Table 4 above shows the summary of both the students and teachers response on the different issues related to the perceived negative impact of supplementary private tutoring from the perspectives of the students and the teachers.

Question number 1, in Table 4 asks about the negative effect of supplementary private tutoring whether it takes their spare time or not. A large percentage of students believe that supplementary private tutoring did not take students spare time. For instance, $(80.3 \%$ and $77.8 \%$ ) of student and teachers respectively believed that it did not take their spare time. While the rest of the participants that is 19.7 percent of students and 22.2 percent of teachers confirm that supplementary private tutoring takes students spare time and can be seen as a perceived negative effects of private tutoring.

Question number 2, and 7, in Table 4 asks about the perceived negative effects of supplementary private tutoring on social stigma of students. A significant percentage of participants confirmed that having a tutor did not create any social stigma among students. For instance, $(91.2 \%$ and $96.1 \%)$ of students and teachers respectively reported that students did not get teased because they have a tutor. Similarly, 91.2 percent of the students and 94.6 percent reported that students did not feel embarrassed to have a tutor.

Question number 3, in the Table 4 asks whether taking supplementary private tutoring is boring or not. A large percentage of students $(86 \%)$ believe that it is not boring. Similarly, 
when teachers are asked the same question a great majority (78.6\%) of respondents believe that supplementary private tutoring is not boring for the students.

Question number 4, 5, and 6, in Table 4 asks whether participating in supplementary private tutoring requires much and extra effort or not. A greater percentage of students for instance 87.8 percent and 71.1 percent of students and teachers believed that supplementary private tutoring you do not have to do more work respectively. On the other hand, $(86.1 \%$ and $78.6 \%)$ of students and teachers respectively confirmed no to the question whether the work they do with their tutors is different to the work they do in school and confuse them. In other words, participants believe that the work they do with their tutor is similar that of the work they do in school.

\section{Discussion}

One of the features of supplementary private tutoring is cost; related to this issue the findings of this study revealed that most of the students and the teachers indicated that per month the amount of money paid for a single student is more than 300 Ethiopian Birr (\$15). This amount of money is relatively very high in Ethiopian context but when we see it in relation to other countries experience it is very small. For instance, a study by Bray (2011) revealed that in different countries such as in Beljium $(€ 33)$, France $(€ 30.50)$, and Ireland $(€ 30)$ per hour for tutoring plus the cost of transportation for the tutor. This result clearly indicates that the cost of tutoring greatly depends up on the type of tutoring given. It is obvious that one-to-one tutoring is generally more costly than tutoring in groups, which in turn is more costly than tutoring in large classes.

Likewise, the result also indicated that whether the cost the family pays for the tutoring is a burden for the family or not is not known by the respondent students it might be because the students may not know its effect on the household. This result is also congruent with the teachers' response that reveals they do not have information about the burden and it is relatively big, but not prohibitively expensive respectively. However, in different countries the amount of money parents pay for the students' supplementary private tutorial is becoming a burden for the family. For instance in Hong Kong a study by Lee (1996) revealed that most of the parents confirmed to the question they asked whether or not the money they pay for supplementary private tutoring is a burden or not and they responded it by saying agree that indicates it is really a burden to the household.

Generally, the proliferation of supplementary private tutoring has positive and negative effects. On the bright side, supplementary private tutoring can have a positive effect on academic achievement and may help students to understand and enjoy their regular classes. Supplementary private tutoring adapts to each student's needs, not having only remedial purposes, but also helping the best students to improve their performance. If supplementary private tutoring helps students to increase their educational outcome, it could be seen as a determinant of economic growth, as economies with large stocks of human capital tend to grow faster. At the same time, attending supplementary private tutoring prevents students 
from doing harmful or less profitable activities.

As it is indicated in the result part of this paper one of the perceived advantage of supplementary private tutoring is it helps students understanding of the subject matter. It helped the students to make things are explained to them in more detail, helped them to discuss issues which are not clear in schools and helped them to learn faster than at school. This result was congruent with the findings of Buchmann (2002) which confirms that supplementary private tutoring contributes the students to fill a gap in knowledge, memorizing and systematizing topics learned earlier, and better understanding topics taught at school. In addition, the same author argues that supplementary private tutoring help students learn subjects more quickly.

Private supplementary tutoring also helps students in providing different support (to get one-to-one help, give someone to talk and ask them any question) and increase the self confidence of the students. Supporting this idea scholar such as Shafiq (2002) pointed out in his study that students have tutors because their schools do not provide enough help. Similarly, Mischo and Haag (2002) conducted a research on grade 5 to 11 students and found out that students who receive private tutoring showed an improvement in school marks, motivation and self confidence.

In this research, one of the finding shows that both student and the teachers perceived that supplementary private tutoring helps to improve students achievement result (helps to achieve the highest examination grades and helps them do better in schools). Substantiating this idea there are few researches that showed the impact of supplementary private tutoring on academic performance of students. Generally, the summary of research findings by Bray and Silova (2006) revealed that it is mixed. Some findings indicate positive result that is better in academic performance, better in reading and less grade repetition. However, some studies found no relation between private tutoring and achievement.

A study conducted by Byun (2011) in the Republic of Korea to compare the effect of tutoring on academic achievement in mathematics for a nationally representative sample of lower secondary students. He found that cram schooling, which focuses primarily on test preparation, made a small difference in achievement gains. However, other forms of tutoring (such as one-to-one, internet, and correspondence) made little difference. To some extent, this refelected the findings of Kang (2009), who also found positive but small effects from investment in tutoring as measured by the experience of 1,752 students tracked by a Korean Education and Employment Panel longitudinal study. Nevertheless, Byun recognized that his study focused only on the quantities of the different types of tutoring received and had no measures of quality.

Another impact of supplementary private tutoring is focuses on social impact. Different authors have pointed out some negative effects of supplementary private tutoring. Firstly, Bray and Bunly (2005) argues that mainstream teachers may "relax" in their duties, as they know that supplementary private tutoring will finally make up for their mistakes (supplementary private tutoring introduces, in a certain way, a moral risk problem). Secondly, Bray and Bunly (2005) explains that the proliferation of supplementary private tutoring may 
distort the organization of the academic curriculum, students giving no importance to those subjects that are not included in the final exams. Nevertheless, this point seems to be more related to the values and culture of the society than to supplementary private tutoring itself, the proliferation of the latter just being a consequence of the former. Thirdly, supplementary private tutoring may increase the absenteeism rates and reduce the interest of students in mainstream classes.

However, the results of this study made clear that participation in supplementary private tutoring did not consume students' spare time. Research evidence on the other hand, in other countries reveal on the contrary. For instance, Huan et al., (2008) pointed out that in their study that when students take supplementary private tutoring they are placed under high levels of pressure and fatigue. The degree of tolerable pressure depends on the culture and social values where the student lives in. This effect unquestionably affects all students, who attend supplementary private tutoring even on weekends and, frequently, until late in the night.

Likewise, Foondun, (1992) in his research found out the pressure and burden of children who participate in supplementary tutoring. For instance, in Mauritius one official has questioned the appropriateness of social force that leads children to spend much hour in a day in both formal schools and private tutoring compared with adults work hours in a day and concluded his remarks by stating children are made to work for longer hours than their parents.

On the other hand, Gauci and Wetz (2009) in their qualitative study showed challenges students faced when examinations approach. They made clear that almost all sample students who took tutoring worried about stress and the shortage of leisure time activities.

\section{Conclusion}

Based on the finding of the study the following conclusions are formulated:

Supplementary private tutoring involves by tutors for financial gain. Accordingly, the amount of money parents pay is relatively big in Ethiopian context so that it is a burden for the family.

From the results it is concluded that supplementary private tutoring helps students understanding of the subject matter, provide different support (to get one-to-one help, give someone to talk and ask them any question) and increase the self-confidence of the students, and improve students achievement result (helps to achieve the highest examination grades and helps them do better in schools).

Related to social impact of supplementary private tutoring it can be concluded that supplementary private tutoring in Ethiopian context did not consume students' spare time, not result in social stigma of students (having a tutor did not create any social stigma among students; students did not get teased because they have a tutor), it is not boring and it did not requires much and extra effort, the work they do with their tutors is the same activity they perform in school and it did not confuse them. 


\section{Recommendation}

Based on the findings and conclusion of the study the following recommendations are formulated:

This study has identified major impacts of private supplementary tutoring on students' academic performance. To overcome the challenges and improve the quality of education in schools of all levels many researches should be conducted in Ethiopia and elsewhere in the world. Researches that focused on this issue would have a paramount importance to improve the process of the school system as well as the tutoring program.

Since the results of this study showed that parents are willing to pay for better education, the government and educational policy makers need to reconsider the policy of free education. Instead of allocating a huge amount of money for implementing free education it would be advisable for the government to introduce some tuition fees and improve the quality of education at all levels. However, the government can provide scholarship to needy students. In addition to reduce high competition to join university, it would be good for the government to increase the number of public universities and encourage private universities.

Supplementary private tutoring has both positive and problematic dimensions. The Ethiopian government ought to recognize the problematic dimensions of the schools and take some necessary measures that help to improve the quality of student learning. It is obvious that the current arrangements of the Ethiopian education system are effective for many, but it may not work for all students. Some need a level of support which is beyond our control to deliver in the context of whole class or small groups. Without an individualized approach it will be very hard for this group to make the progress needed to achieve their full potential.

Policy makers are advised to pay more attention to the incidence of private tutoring. From economic perspective, private tutoring involves equity and efficiency considerations, which in turn establish what stance should policy makers take towards tutoring. Such a process requires a comprehensive analysis incorporating, among others, rates of return to private tutoring; cost effectiveness of private tutoring and the potential over generational transmission of income inequality through inequality of current private tutoring opportunities. Therefore, more and in-depth academic research in this area of interest is essential. Equity considerations are arguably a priority as household income is found in the current study as a positive significant deriving force of both private tutoring decision and expenditure.

\section{Acknowledgement}

We generated the primary data for this article from part of the research project of the corresponding author, which is fully funded by the College of Education and Behavioral Sciences, Jimma University (JU), Ethiopia. We are grateful to JU's institutional support. Moreover, we are indebted to the study's participants who took their time and energy to provide interviews and participate in focus group discussion and filling questionnaires. 


\section{References}

Aggarwal, Y. (1998). Primary education in Delhi: how much $\backslash$ Do the children learn? New Delhi: National Institute of Educational Planning and Administration.

Bajaj M., \& Belinda C. (2009). Education for Sustainable Development as Peace Education, Peace and Change, 34(4), 441-455. https://doi.org/10.1111/j.1468-0130.2009.00593.x

Banerjee, A. V., Cole, S., Duflo, E., \& Linden, L. (2007). Remedying education: Evidence from two randomized experiments in India. Quarterly Journal of Economics, 122(3), 1235-1264. https://doi.org/10.1162/qjec.122.3.1235

Baker et al. (2001). Worldwide Shadow Education: Outside-School Learning, Institutional Quality of Schooling, and Cross-National Mathematics Achievement. Educational Evaluation and Policy Analysis, 23(1), 1-17. https://doi.org/10.3102/01623737023001001

Bray, M. (1999). The shadow education system: private tutoring and its implication. Paris: UNESCO-IIEP.

Bray, M. (2003). Adverse effects of private supplementary tutoring. Paris: UNESCO-IIEP.

Bray, Mark \& Seng Bunly. (2005). Balancing the Books: Household Financing of Basic Education in Cambodia. Washington DC: World Bank, and Hong Kong: Comparative Education Research Centre, The University of Hong Kong. Retrieved from http://www0.hku.hk/cerc/Publications/cambodia.htm

Bray, Mark \& Iveta Silova. (2006). "The Private Tutoring Phenomenon: International Patterns and Perspectives." Pp.27-41 in Education in a Hidden Marketplace: Monitoring of Private Tutoring.

Bray, Mark. (2011). The Challenge of Shadow Education: Private Tutoring and its Implications for Policy Makers in the European Union. Brussels: European Commission. Available on-line: http://www.nesse.fr/nesse/activities/reports/the-challenge-of-shadow-education-

Bray, M. (2013). Benefits and tensions of shadow education: comparative perspectives on the roles and impact of private supplementary tutoring in the lives of Hong Kong students. Journal of International and Comparative Education, 2(1), 18-30. https://doi.org/10.14425/00.45.72

Buchmann, Claudia. (2002). "Getting Ahead in Kenya: Social Capital, Shadow Education, and Achievement." Pp133-159 in Schooling and Social Capital in Diverse Cultures. Oxford: Elsevier Science Ltd.

Byun, Soo-yong. (2011). "Shadow Education and Academic Success in South Korea." College of Education, Pennsylvania State University. Downloaded 2 December 2011 from: https://sites.google.com/site/sooyongbyunshomepage/research-2

Cheo, Roland \& Euston Quah. (2005). Mothers, Maids and Tutors: An Empirical Evaluation 
of Their Effect on Children's Academic Grades in Singapore. Education Economics 13(3), 269-285. https://doi.org/10.1080/09645290500073746

Dang, Hai-Anh. (2007). The Determinants and Impact of Private Tutoring Classes in Vietnam. $\begin{array}{llll}\text { Economics of Education } & \text { Review, 684-699. }\end{array}$ https://doi.org/10.1016/j.econedurev.2007.10.003

Dang, H.-A., \& Rogers, F.H. (2008) The Growing Phenomenon of Private Tutoring: does it deepen human capital, widen inequalities, or waste resources? World Bank Research Observer, 23(2), 161-200. https://doi.org/10.1093/wbro/lkn004

Dawson, Walter. (2010). Private Schooling and Mass Schooling in East Asia: Reflections of Inequality in Japan, South Korea, and Cambodia. Asia Pacific Education Review, 11(1), 14-24. https://doi.org/10.1007/s12564-009-9058-4

Foondun, R. A. (2002). The issue of private tuition: The practice in Mauritius and selected South-East Asian countries. International Review of Education, 48(6), 485-515. https://doi.org/10.1023/A:1021374811658

Gauci, D., \& Wetz, S. (2009) The Private Lessons Phenomenon in a Form Five Girls' Mathematics Classroom, BEd (Hons) dissertation, University of Malta.

Glewwe, Paul, Hanushek, Eric, Humpage, Sarah, \& Ravina, Renato (2013). School Resources and Educational Outcomes in Developing Countries: A Review of the Literature from 1990 to 2010. Education Policy in Developing Countries (ed. by Paul Glewwe), University of Chicago Press, Chicago. https://doi.org/10.7208/chicago/9780226078854.003.0002

Ha, T. T., \& Harpham, T. (2005). Primary education in Vietnam: extra classes and outcomes. International Education Journal, 6(5), 626-634.

Hamid, M. Obaidul, Roland Sussex \& Asaduzzaman Khan. (2009). Private Tutoring in English for Secondary School Students in Bangladesh. TESOL $\backslash$ Quarterly, 43(2), 281-308. https://doi.org/10.1002/j.1545-7249.2009.tb00168.x

Hanushek, Eric (2003). The Failure of Input-based Schooling Policies. The Economic Journal, 113(February), F64-F98. https://doi.org/10.1111/1468-0297.00099

Huan, V.S., Yeo, L. S., Ang, R.P., \& Chong, W.H. (2008). The Impact of Adolescent Concerns on their Academic Stress. Educational Review, 60(2), 169-178. https://doi.org/10.1080/00131910801934045

Ireson, Judith. (2004). Private Tutoring: How Prevalent and Effective is it? London Review of Education, 2(2), 109-122. https://doi.org/10.1080/1474846042000229458

Jackson L. Sherri. (2009). Research Methods and Statistics A Critical Thinking Approach (3rd ed). New York: Wadsworth.

Kang, Changhui. (2009). "Does Money Matter? The Effect of Private Education Expenditures on Academic Performance in the Republic of Korea," in Barrera-Osorio, 


\section{Macrothink}

Felipe; Patrinos, Harry Anthony and Wodon, Quentin (eds.), Emerging Evidence on Vouchers and Faith-Based Providers in Education: Case Studies from Africa, Latin America, and Asia. Washington DC: World Bank, pp.151-164.

Kirss, Laura (2011). Education in the Shadows: The Case of Estonia. Tallinn: Center for Policy Studies.

Kuan, Ping-Yin. (2011). Effects of Cram Schooling on Mathematics Performance. Comparative Education Review, 55(3), 342-368. https://doi.org/10.1086/659142

Lavy, Victor \& Analia Schlosser. (2005). Targeted Remedial Education for Underperforming Teenagers: Costs and Benefits. Journal of Labor Economics, 23(4), 839-874. https://doi.org/10.1086/491609

Lee, C. (1996). Children and Private Tuition. Youth Poll Series No.34. Hong Kong Federation of Youth Groups, Hong Kong.

Liu, J. (2009). Cram Schooling in Taiwan. Journal of Youth Studies [Hong Kong], 12(1), 129 136.

Mendes, A., Costa, J. A., Ventura, A., Azevedo, S., \& Gouveia, A. (2013). Private tutoring in Portugal: Patterns and impact at different levels of education. In M. Bray, A. E. Mazawi and R. G. Sultana (eds.). Private tutoring across the Mediterranean: Power dynamics and implications for learning and equity (pp. 151-165). Rotterdam: Sense Publishers. https://doi.org/10.1007/978-94-6209-237-2_9

Mischo, Christoph \& Haag, Ludwig. (2002). Expansion and Effectiveness of Private Tutoring. European Journal of Psychology of Education, XVII(3), 263-273. https://doi.org/10.1007/BF03173536

Monbukagakusho. (2008). Kodomono gakkougai deno gakushu katsudo ni kansuru jittai chosa houkokusho [A national survey on child's out-of-school learning activities].

Nath, Samir Ranjan. (2008). Private Supplementary Tutoring among Primary Students in Bangladesh. Educational Studies, $\quad 34(1), \quad 55-72$. https://doi.org/10.1080/03055690701785285

Russell, Jenni. (2002). The Secret Lessons. New Statesman, 8 April, 10-13.

Shafiq, M.N. (2002). The economic burden of private tutoring expenses on households in developing countries: the case of Bangladesh. (Paper presented at the Annual Conference of the Comparative and International Education Society, Orlando, Florida.)

Simona P. (2007). Defensible Spaces: Ideologies of Professionalism and Teachers' Work in the Romanian Private Tutoring System, PhD dissertation, University of Pittsburgh.

Sullivan, P. (2010). As Private Tutoring Booms, Parents Look at the Returns. New York Times, August 21.

Suryadarma, D., Suryahadi, A., Sumarto, S., \& Rogers, F. H. (2006). Improving student 
performance in public primary schools in developing countries: Evidence from Indonesia. Education Economics, 14(4), 401-429. https://doi.org/10.1080/09645290600854110

World Bank (2012). Diagnosis Corruption in Ethiopia: Perceptions, Realities, and the way forward for key sectors. Washington DC

\section{Copyright Disclaimer}

Copyright for this article is retained by the author(s), with first publication rights granted to the journal.

This is an open-access article distributed under the terms and conditions of the Creative Commons Attribution license (http://creativecommons.org/licenses/by/3.0/). 